\title{
PERAN TAMAN BACAAN MASYARAKAT (TBM) BAGI ANAK-ANAK USIA DINI
}

\author{
Encang Saepudin ${ }^{1}$, Sukaesih $^{2}$, Agus Rusmana ${ }^{3}$ \\ 1,2,3 Program Studi Ilmu Perpustakaan Universitas Padjadjaran \\ 1encang@unpad.ac.id, ${ }^{2}$ sukaesih@unpad.ac.id, ${ }^{3}$ a.rusmana@unpad.ac.id
}

\begin{abstract}
This activity examines the role of the Community Library (TBM) For Early Childhood In the village Narawita Cicalengka District of Bandung regency. Method or Participatory Rural Appraisal Techniques and data collection through interviews, observation, focus group discussions, and literature study aims to determine the role of these activities bancaan community garden teutama on the tasks and functions of public reading in improving learning skills in early childhood. The results show that the public reading in a village environment Narawita serve as a source of learning early age children, resources for parents in fostering early childhood-education and recreational facilities for the community. Thus the public reading can serve as a learning tool for both kids an early age and the parents children-especially young housewife in expanding their knowledge.
\end{abstract}

Keywords: Libraries, early childhood, learning resources, sources information recreationeducation.

ABSTRAK - Kegiatan ini mengkaji tentang Peran Taman Bacaan Masyarakat (Tbm) Bagi AnakAnak Usia Dini di Desa Narawita Kecamatan Cicalengka Kabupaten Bandung. Dengan Metode atau Teknik Participatory Rural Appraisal dan teknik pengumpulan data melalui wawancara, observasi, Focus Group Discussion, dan studi pustaka kegiatan ini bertujuan mengetahui peran taman bacaan masyarakat teutama mengenai tugas dan fungsi taman bacaan masyarakat dalam meningkatkan kemampuan belajar pada anak usia dini. Hasil kajian menunjukkan bahwa taman bacaan masyarakat yang ada di lingkungan Desa Narawita berperan sebagai sumber belajar anakanak usia dini, sumber informasi bagi para orang tua dalam membina anak usia dini, dan sarana rekreasi-edukasi bagi masyrakat. Dengan demikian taman bacaan masyarakat dapat berperan sebagai sarana belajar baik bagi anak-anak usia dini maupun para orang tua anak-anak terutama ibu rumah tangga muda dalam memperluas pengetahuan mereka
Kata kunci: Taman bacaan, anak usia dini, sumber belajar, sumber informasi rekreasi-edukasi.

\section{PENDAHULUAN}

Desa Narawita Kecamatan Cicalengka

Kabupaten Bandung Jawa Barat merupakan desa yang sebagian besar penduduknya berpenghidupan sebagai petani tradisional, terutama sawah dan ladang sebagai lahan utama usaha pertanian mereka. Sawah sebagai lahan penghidupan utama di sektor pertanian di desa ini tidak bertambah, bahkan semakin berkurang akibat bertambahnya penduduk yang bermukim di sini.

Tidak semua petani di Desa Narawita memiliki tanah atau sawah sebagai lahan utama penghidupan mereka. Sekitar sepertiga dari penduduk di desa ini hanya sebagai petani penggarap dan buruh tani. Mereka rata-rata hanya sebagai buruh tani yang ikut menggarap lahan pesawahan atau ladang kepada pemilik tanah. Sementara itu, sebagian lain dari mereka bekerja sebagai pedagang, pemelihara ayam kampung secara tradisional, dal lain-lain. Oleh karena itu, sebagian penduduk masih ada dalam kategori penduduk miskin.

Sebagian besar anak-anak dari keluarga atau penduduk miskin yang ada di desa Narawita tidak memiliki kesempatan untuk mengikuti pendidikan 
pra sekolah baik pendidikan formal (taman-kanakkanak) maupun informal (Bambim, PAUD nonformal). Bahkan sebagian dari mereka ada yang tidak bisa menuntaskan wajib belajar 9 tahun. Hal ini disebabkan oleh ketiadaan biaya untuk biaya sekolah (untuk membeli pakaian seragam, buku, dan lain-lain) yang cukup besar menurut ukuran mereka. Sedangkan berdasarkan pada jumlah penduduk, usia anak-anak mencapai 30\% yakni 1.677 jiwa.

Encang Saepudin dalam Literasi Media Bagi Guru Paud di Kecamatan Cicalengka menyatakan bahwa, pendidikan prasekolah menjadi dasar bagi pendidikan sekolah pada jenjang lebih tinggi. Pendidikan usia dini merupakan proses pendidikan mendasar dan peletakan nilai-nilai kehidupan secara dini. Oleh karena itu, proses pendidikan pada masa prasekolah ini tidak bisa dilaksanakan secara sembarangan dan asal-asalan. Proses pendidikan pada masa prasekolah ini harus terencana dengan baik dengan tujuan capaian pembelajaran yang terukur yakni tertanamnya karakter positif pada diri setiap anak. Dalam hal ini pendidikan prasekolah merupakan proses pembentukan karakter anak. Upaya pembentukan karakter untuk membangun manusia cerdas baik dari segi intelektual maupun moral harus dilakukan sejak dini (Saepudin, 2016).

Para pakar psikologi menyatakan bahwa masa awal kehidupan merupakan masa-masa yang menentukan terhadap pembentukan kepribadian. Pada dasarnya inti dari pendidikan karakter yaitu membimbing individu untuk membentuk perilaku adaptif (Eliasa, 2011). Apabila pendidikan karakter ini dilaksanakan sejak dini akan terjadi internalisasi nilai moral dalam diri dan perilaku anak. Sehingga secara bertahap nilai moral tersebut akan mewarnai kepribadian anak. Tertanamnya nilai-nilai luhur pada diri anak akan membangun perilaku positif pada diri anak.

Menurut Undang-Undang Republik Indonesia Nomor 20 Tahun 2003 tentang Sistem Pendidikan Nasional, mengacu pada data tahun 2001, dari 26,1 juta anak yang ada di Indonesia baru 7,1 juta atau sekitar $28 \%$ anak yang telah mendapatkan pendidikan. Terdiri atas 9,6\% terlayani di bina keluarga bawah lima tahun, 6,5\% di taman kanakkanak, 1,4\% Raudhatul Athfal, 0,13\% di kelompok bermain, $0,05 \%$ di tempat penitipan anak lainnya, 9,9\% terlayani di sekolah dasar (Menteri Pendidikan Nasional R.I., 2003). Ini menunjukkan, pentingnya pendidikan usia dini belum mendapatkan perhatian dengan baik.

Hal tersebut terjadi pula di lingkungan Desa Narawita. Sebagian besar anak-anak dari keluarga atau penduduk miskin, tidak memiliki kesempatan untuk mengikuti pendidikan pra sekolah baik pendidikan formal (taman-kanak-kanak) maupun informal (Bambim, PAUD non-formal). Bahkan sebagian dari mereka ada yang tidak bisa menuntaskan wajib belajar 9 tahun. Hal ini disebabkan oleh kekurangan biaya untuk biaya sekolah (untuk membeli pakaian seragam, buku, dan lain-lain) yang cukup besar menurut ukuran mereka. Sedangkan berdasarkan pada jumlah penduduk usia anak-anak mencapai 30\% yakni 1.677 jiwa.

Hal ini terjadi karena Penduduk Desa Narawita Kecamatan Cicalengka Kabupaten Bandung Jawa Barat adalah desa yang sebagian besar berpenghidupan sebagai petani tradisional, terutama sawah dan ladang sebagai lahan utama 
usaha pertanian mereka. Sawah sebagai lahan penghidupan utama di sektor pertanian di desa ini tidak bertambah, bahkan semakin berkurang akibat bertambahnya penduduk yang bermukim di sini. Tidak semua petani di Desa Narawita memiliki tanah atau sawah sebagai lahan utama penghidupan mereka. Sekitar sepertiga dari penduduk di desa ini hanya sebagai petani penggarap. Mereka rata-rata hanya sebagai buruh tani yang ikut menggarap lahan pesawahan atau ladang kepada pemilik tanah. Sementara itu, sebagian lain dari mereka bekerja sebagai pedagang, pemelihara ayam kampung secara tradisional, dal lain-lain. Oleh karena itu, sebagian penduduk masih ada dalam kategori penduduk miskin.

Dengan hadirnya TBM ini menjadi salah satu penyelesaian masalah yang dihadapi masyarakat terutama masyarakat yang memiliki anak balita dan memiliki keterbatasan secara ekonomi. Dalam hal ini TBM memiliki peran sebagai penyedia jasa pelayanan membaca dengan cara menyediakan bahan bacaan dan pendampingan belajar membaca bagi anak-nak usia dini dari keluarga yang kurang mampu.

Berdasarkan uraian di atas, maka tujuan kajian ini adalah mengetahui peran taman bancaan masyarakat teutama mengenai tugas dan fungsi taman bacaan masyarakat dalam meningkatkan kemampuan belajar anak usia dini

\section{TINJAUAN PUSTAKA}

Untuk meningkatkan minat baca masyarakat sebagai bentuk tindak lanjut dan pemeliharan pembelajaran yang berkelanjutan dibutuhkan dukungan tokoh masyarakat, masyarakat, keluarga, dan lembaga pemerintah. Pembangunan taman bacaan masyarakat merupakan suatu bentuk keterlibatan seluruh unsur dalam membangun minat membaca masyarakat. Dalam Petunjuk Teknis Pengajuan dan Pengelolaan Taman Bacaan Masyarakat, disebutkan bahwa taman bacaan masyarakat adalah lembaga pembudayaan kegemaran membaca masyarakat yang menyediakan dan memberikan layanan di bidang bahan bacaan, berupa: buku, majalah, tabloid, koran, komik, dan bahan multi media lain, yang dilengkapi dengan ruangan untuk membaca, diskusi, bedah buku, menulis, dan kegiatan literasi lainnya, dan didukung oleh pengelola yang berperan sebagai motivator (Direktur Jenderal Pendidikan Anak Usia Dini, Nonformal, 2012).

Hal ini sejalan dengan pendapat Encang Saepudin dalam Tingkat Budaya Membaca Masyarakat yang menyatakan bahwa, berseminya budaya baca adalah kebiasaan membaca, sedangkan kebiasaan membaca terpelihara dengan tersedianya bahan bacaan yang baik, menarik, memadai, baik jenis, jumlah maupun mutunya. Inilah sebuah formula yang secara ringkas untuk mengembangkan minat dan budaya baca (Saepudin, 2016b). Dari rumusan konsepsi tersebut, tersirat tentang perlunya minat baca tersebut dibangkitkan sejak usia dini (kanakkanak).

Kegiatan perluasan dan penguatan taman bacaan masyarakat merupakan upaya pemerintah untuk meningkatkan kualitas layanan dan hasil pendidikan keaksaraan melalui taman bacaan masyarakat. Penguatan taman bacaan masyarakat ini bertujuan untuk meningkatkan mutu layanan di bidang bahan bacaan dan pelaksanaan kegiatan 
literasi kepada masyarakat dengan: (1) diharapkan juga dapat meningkatkan Memperkaya variasi koleksi bahan bacaan, (2) Menyediakan tempat yang nyaman, aman, dan menyenangkan, (3) Menyediakan sarana berubah dari masyarakat pra sejahtera menjadi masyarakat sejahtera yang ada di daerah.

pendukung yang memadai, dan (4) Melaksanakan kegiatan-kegiatan pembudayaan kegemaran membaca (literasi) sesuai dengan kebutuhan dan potensi lokal, (5) Menggali produk unggulan yang menjadi ciri khas daerah yang memungkinkan untuk diberdayakan secara komersial oleh masyarakat.

Tujuan Penyelenggaraan taman bacaan masyarakat dimaksudkan untuk menyediakan akses sarana pembelajaran yang menyediakan dan memberi layanan bahan bacaan yang merata, meluas, dan terjangkau oleh masyarakat dengan mudah dan murah. Adapun tujuannya adalah: (1) Meningkatkan kemampuan keberaksaraan dan keterampilan membaca,

Menumbuhkembangkan minat dan kegemaran membaca, (3) Membangun masyarakat membaca dan belajar, (4) Mendorong mewujudkan masyarakat pembelajar sepanjang hayat, (5) Mewujudkan kualitas dan kemandirian masyarakat yang berpengetahuan, berketerampilan, berbudaya maju, dan beradab.

Dari tujuan dan fungsi tersebut di atas dapat disimpulkan bahwa dengan adanya taman bacaan masyarakat diharapkan masyarakat dapat meningkatkan pengetahuan dan keterampilannya dalam segala bidang dan mampu mengali produk unggulan yang menjadi ciri khas daerah tersebut. Dengan peningkatkan pengetahuan dan keterampilan, maka sumberdaya manusia pada daerah miskin diharapkan mampu bersaing untuk mendapatkan lapangan pekerjaaan sehingga

\section{METODE PENELITIAN}

Penelitian ini menggunakan pendekatan kualitatif. Pendekatan kualitatif memfokuskan telaahnya pada makna-makna subyektif, pengertian-pengertian, metafor-metafor, simbolsimbol, dan deskripsi-deskripsi ihwal suatu kasus spesifik yang hendak diteliti. Pendekatan ini dipilih agar studi ini memperolah gambaran detail dan mendalam informasi mengenai suatu gejala sosial tertentu yang bersifat fenomenologis. Untuk memperkuat perolehan data lapangan, proses pengumpulan data menggunkan teknik Participatory Rural Appraisal (PRA) (Djohani, 2003).

Berdasarkan tujuannya, penelitian ini termasuk dalam kategori penelitian deskriptif, yaitu penelitian yang berusaha menggambarkan rincian-rincian spesifik dari situasi, setting atau relasi-relasi sosial yang berlangsung dalam lingkup subyek penelitian. Informan dalam penelitian ini yakni para pengelola Taman Bacaan Masyarakat Mutiara Harapan, kader PKK Desa Narawita, dan tokoh mayarakat berjumlah 11 orang. Teknik pengumpulan data melalui observasi, wawancara, focus group discussion, dan studi pustaka. Teknis analisis data yang digunakan adalah analisis data deskriptif dengan langkah reduksi data, penyajian data, dan penarikan kesimpulan. Uji validitas dan reliabilitas yang dilakukan yakni melalui proses trianggulasi data dan trianggulasi sumber. 


\section{HASIL DAN PEMBAHASAN}

Desa Narawita merupakan salah satu dari 12 Desa yang berada diwilayah Kecamatan Cicalengka Kabupaten Bandung Propinsi Jawa Barat. Desa Narawita berpenduduk 5.595 jiwa, perempuan 2723 jiwa dan laki-laki 2876 jiwa dengan Luas Wilayah Desa 302 Ha. Selain itu, jumlah penduduk berdasarkan usia terdiri atas 0 14 berjumlah 1.677 jiwa, 14-64 berjumlah 3.795 jiwa, dan 65 ke atas berjumlah 127 jiwa. Ditinjau dari jumlah penduduk dan luas wilayah tersebut, maka Desa Narawita merupakan desa yang sangat potensial dalam mendukung pelaksanaan pembangunan di wilayah Kecamatan Cicalengka. Walaupun letaknya cukup jauh dari kecamatan namun desa ini berbatasan dengan desa yang ada di Kecamatan Nagreg dan kecamatan Cikancung. Selain itu, Desa Narawita sebagai penghubung melalui jalur transportasi lewat darat antar ke-3 kecamatan tersebut.

Desa Narawita Kecamatan Cicalengka dilihat dari topografi dan kontur tanah secara umum berupa dataran tinggi dan lereng gunung yang berada pada ketinggian $700 \mathrm{mdl}$. di atas permukaan laut. Desa Narawita terdiri dari empat dusun yang dikepalai oleh 4 Kepala Dusun, 13 RW dan 30 RT. Mengingat keadaan di atas, dalam melaksanakan berbagai tugas kepala desa terus memacu para perangkat desa dan masyarakat serta lembaga yang ada di desa seperti BPD, LPMD, Tim Penggerak PKK Desa, Linmas, GAPOKTAN, beserta para tokoh Agama dan tokoh masyarakat dalam rangka melaksanakan pembangunan menuju peningkatan Kinerja Pembangunan Desa.
Desa ini adalah desa yang sebagian besar penduduknya berpenghidupan sebagai petani tradisional, terutama sawah dan ladang sebagai lahan utama usaha pertanian mereka. Sawah sebagai lahan penghidupan utama di sektor pertanian di desa ini tidak bertambah, bahkan semakin berkurang akibat bertambahnya penduduk yang bermukim di sini.

Tidak semua petani di Desa Narawita memiliki tanah atau sawah sebagai lahan utama penghidupan mereka. Sekitar sepertiga dari penduduk di desa ini hanya sebagai petani penggarap. Mereka rata-rata hanya sebagai buruh tani yang ikut menggarap lahan pesawahan atau ladang kepada pemilik tanah. Sementara itu, sebagian dari mereka bekerja sebagai pedagang, pemelihara ayam kampung secara tradisional, dan lain-lain. Oleh karena itu, sebagian penduduk masih ada dalam kategori penduduk miskin. Sebagian besar anak-anak dari keluarga atau penduduk miskin sebagaimana disebutkan pada paragraf di atas, tidak memiliki kesempatan untuk mengikuti pendidikan pra sekolah baik pendidikan formal (taman-kanak-kanak) maupun informal (Bambim, PAUD non-formal). Bahkan sebagian dari mereka ada yang tidak bisa menuntaskan wajib belajar 9 tahun. Hal ini disebabkan oleh ketiadaan biaya untuk biaya sekolah (untuk membeli pakaian seragam, buku, dan lain-lain) yang cukup besar menurut ukuran mereka. Sedangkan berdasarkan pada jumlah penduduk usia anak-anak mencapai 30\% yakni 1.677 jiwa.

Padahal, pendidikan pra sekolah dinilai menjadi pendidikan yang menjadi dasar bagi pendidikan selanjutnya. Mendidik anak tidak dapat secara asal-asalan, dikarenakan nilai penting 
pendidikan usia dini. Hal ini mengingat pendidikan tidak dapat dilaksanakan secara mendadak ketika anak sudah besar. Justru ketika masih kecil itulah pendidikan perlu direncanakan sebaik mungkin. karena pendidikan pada masa itu merupakan proses meletakkan dasar dan pondasi. Pendidikan lanjutan tinggal meneruskan apa yang telah diperoleh ketika kecil. Pendidikan dalam bentuk pembiasaan, penanaman nilai-nilai, serta aspek-aspek dasar terjadi ketika anak-anak masih kecil. Untuk itulah setiap lembaga pendidikan pra sekolah harus memiliki dasar-dasar seperti itu secara kokoh dan komprehensif.

Untuk mendongkrak kesempatan belajar khusunya anak usia dini, sebagai bentuk tindak lanjut pembelajaran yang berkelanjutan dibutuhkan dukungan pihak keluarga, tokoh masyarakat, masyarakat secara umum, pemerintah, dan lembaga sosial kemasyarakatan. Dengan terintegrasinya berbagai elemen masyarakat diharapkan terbentuknya lembagalembaga kemasyarakatan yang bergerak dalam bidang pendidikan dan penyediaan bahan bacaan. Lembaga tersebut seperti perpustakaan, rumah baca atau Taman Bacaan Masyarakat (TBM).

Dalam Keaksaraan dalam Wacana Global: Media Komunikasi Pendidikan Keaksaraan (Aksara) disebutkan bahwa, taman bacaan masyarakat adalah lembaga pembudayaan kegemaran membaca masyarakat yang menyediakan dan memberikan layanan di bidang bahan bacaan, berupa: buku, majalah, tabloid, koran, komik, dan bahan multi media lain, yang dilengkapi dengan ruangan untuk membaca, diskusi, bedah buku, menulis, dan kegiatan literasi lainnya, dan didukung oleh pengelola yang berperan sebagai motivator

(Direktorat

Pendidikan Masyarakat, 2009).

\section{Konsep Peran}

Peran merupakan gambaran dari tugas dan fungsi seseorang dalam kehidupan sosial. Dalam hal ini peran merupakan tugas dan fungsi utama yang melekat pada diri seseorang untuk dijalankan baik sebagai individu maupun sebagai kelompok. Manusia sebagai makhluk sosial tidak bisa hidup sendiri sebagai individu, namun hidup dalam kelompok. Pada kehidupan kelompok pasti terjadi interaksi. Interaksi atau hubungan antar anggota dapat menciptakan hubungan timbal balik. Dalam hubungan timbal balik antar anggota kelompok ini yang telah melahirkan peran. Peran memiliki sifat dinamis dalam kehidupan seseorang. Dengan demikian apabila seseorang menjalankan tugas dan fungsinya atau menjalankan hak dan kewajibannya, berarti seseorang tersebut sudah menjalankan perannya.

Berdasarkan paparan di atas dapat disimpulkan bahwa, dalam peran terdapat unsur individu sebagai subyek yang melakukan tugas dan kewajiban dalam masyarakat. Peranan yang melekat pada diri seseorang harus dibedakan dengan posisi dalam pergaulan kemasyarakatan. Peranan lebih banyak menunjuk pada fungsi, penyesuaian diri, dan sebagai suatu proses. Jadi, seseorang menduduki suatu posisi dalam masyarakat berarti ia menjalankan suatu peranan. Hal ini berarti bahwa taman bacaan masyarakat akan bisa menjalankan perannya secara tepat apabila Taman Bacaan Masyarakat memiliki kedudukan (status) dalam masyarakat dan memiliki tugas dan fungsi yang jelas. Oleh karena itu, penyediaan sarana belajar masyarakat yang 
memasyarakat seperti TBM memerlukan daya dukung dari seluruh lapisan masyarakat. Dengan dukungan berbagai elemen masyarakat maka peran taman bacaan ini akan lebih terasa oleh masayarakat itu sendiri.

Perluasan dan penguatan taman bacaan masyarakat merupakan upaya masyarakat dan pemerintah sebagai upaya untuk meningkatkan kualitas pelayanan pendidikan. Melalui pendidikan informal diharapkan kualitas pendidikan menjadi semakin baik dan berkarakter. Dengan hadirnya taman bacaan masyarakat ini masyarakat menjadi memiliki sarana belajar secara mandiri. Hal ini sesuai dengan fungsi TBM yakni sumber belajar, pusat informasi, dan pusat rekreasi berbasis belajar. Dengan disediakan berbagai koleksi yang selaras dengan penggunanya baik berupa buku, majalah, surat kabar ataupun media lain maka taman bacaan ini berpungsi sebagai pusat belajar. Masyarakat dalam hal ini anak-anak usia dini bisa memanfaatkan koleksi yang disediakan taman bacaan sebagai sumber belajar. Mereka belajar membaca, membaca, berhitung, bahkan menggambar. Oleh karena itu, dapat dikatakan taman bacaan masyarakat dapat memperluas wawasan masyarakat penggunanya dan sebagai media belajar sepanjang hayat. Selain anak-anak sebagai target utama taman bacaan masyarakat ini adalah para ibu rumah tangga muda. Ibu rumah tangga muda yang dimaksud adalah para orang tua anak-anak usia dini. Untuk segmentasi ini, taman bacaan masyarakat berfungsi sebagai pusat informasi.

TBM sebagai sumber informasi terlihat dari dua sisi yakni dari segi koleksi yang disediakan dan dari segi pelayanan yang diberikan. Kolesi yang disediakan untuk para orang tua lebih pada koleksi-koleksi ringan yakni majalah, tabloid, booklet-leaflet dan lain-lain. Hal ini disediakan dengan pertimbangan para orang tua anak usia dini lebih membutuhkan informasi-informasi ringan seperti cara merawat tubuh, memasak, membuat kerajinan dan lain-lain. Sedangkan dari sisi pelayanan terlihat dari segi pelayanan konsultasi dan program parenting. Untuk para orang tua anak usia dini disediakan pelayanan konsultasi mengenai perkembangan belajar anakanak, konsultasi mengenai cara membimbing belajar anak di rumah dan lain-lain. Apabila dilihat dari pelayanan yang diberikan ini para orang tua sangat terbantu untuk memecahkan permasalahan yang dihadapinya terutama mengenai membimbing anak.

Peran yang ketiga yakni sebagai pusat rekreasi berbasis belajar. Peran ini sangat kentara dalam pelayanan yang diberikan oleh pihak taman bacaan masyarakat. Para anak usia ini yang menjadi target layanan bukan hanya disediakan koleksi buku sebagai sarana belajar, namun disediakan pelayanan yang berupa permainan seperti alat permainan dalam ruangan dan alat permainan di luar ruangan. Alat permainan di dalam ruangan disediakan alat merangkai balok, merangkai angka dan huruf (pohon angka dan huruf), dan lain-lain. Sedangan alat permainan di luar ruangan seperti cawan putar, tanggga majemuk, dan luncuran. Hal ini disediakan sebagai daya tarik untuk anak-anak agar mau datang dan betah di taman bacaan. Mereka selain bermain/berekreasi dapat sambil belajar. Sebagai contoh penggunaan alat bermain merangkai balok. 
Selain mereka bermain, mereka dapat mengenal mengenai berbagai bentuk. Dari permainan merangkai huruf, anak-anak mengenal berbagai jenis huruf. Begitu pun ketika berbmain merangkai angka, mereka mengenal berbagai bentuk angka.

Dari tujuan dan fungsi tersebut di atas disimpulkan bahwa, adanya taman bacaan masyarakat, diharapkan dapat meningkatkan pengetahuan, keterampilan dalam segala bidang dan mampu mengali produk unggulan yang menjadi ciri khas daerah ini. Peningkatkan pengetahuan dan keterampilan, diharapkan sumberdaya manusia pada daerah ini mampu bersaing untuk mendapatkan lapangan pekerjaan, dapat meningkatkan kesejahteraan hidup sehingga pada akhirnya dapat berubah dari masyarakat pra sejahtera (miskin) menjadi masyarakat sejahtera.

\section{Peran Taman Bacaan Masyarakat}

Sesuai dengan fungsinya, peran taman bacaan masyarakat sebagai adalah sarana belajar, pusat informasi, dan sarana rekreasi berbasis belajar. Hal ini sejalan dengan ketentuan yang dikeluarkan oleh Direktorat Pendidikan Masyarakat, Direktorat PNFI Depdiknas, yang menyatakan bahwa Taman Bacaan Masyarakat tempat atau ruang yang disediakan untuk menyimpan, memelihara, menggunakan koleksi buku, majalah, koran, dan bahan multi media lain untuk dibaca, dipelajari, dibicarakan, dan dimanfaatkan oleh masyarakat secara perseorangan, kelompok atau kelembagaan (Direktorat Pendidikan Masyarakat, 2008). Pengertian ini menunjukkan bahwa taman bacaan masyarakat harus mempunyai sarana prasarana yang memadai. Gong dan Irhkam menyatakan bahwa, "memaksimalkan ruang serta sarana prasarana merupakan upaya untuk memperkuat dan meningkatkan mutu taman bacaan masyarakat agar dapat meningkatkan minat baca masyarakat nan memperbanyak berbagai kegiatan literasi" (Gong dan Irkham, 2011).

Tempat yang kurang luas menjadikan Taman Bacaan Permata Hati terlihat kurang menarik dan terbatas dalam melayani para pembaca. Hal ini perlu penyelesaian dan langkah nyata untuk memaksimalkan penyelengaraanya. Gong dan Irhkam menyatakan bahwa, "taman bacaan masyaraat akan bertahan baik jika tempat yang digunakanya terletak pada tempat yang strategis yang diimbangi dengan tempat penyimpanan buku dan yang terkait itu memadai dan luas" (Gong dan Irkham, 2011).

Sedangkan menurut Peraturan Menteri Pendidikan Nasional No. 48 Tahun 2010, penguatan dan perluasan adalah stimulan, artinya pancingan untuk budaya membaca melalui penyediaan bahan bacaan taman bacaan masyarakat dapat memotivasi/mendorong dan mengajak masyarakat berpartisipasi aktif dalam mencari sumber informasi yang mudah, murah, dan merata. Serta penyelenggaraan sarana TBM dalam pengembangan budaya baca melalui (Menteri Pendidikan Nasional R.I., 2010). Pengertian ini menunjukan bahwa tempat menjadi penting bagi kegiatan literasi, yang disadari betul oleh penyelengara.

Untuk memelihara keberlangsungan penyelenggaraan taman bacaan masyarakat dan eksistensinya diperlukan berbagai alternatif dalam pengelolaanya. Berjalannya pelayanan taman bacaan masyarakat membuat warga dapat belajar 
memanfaatkan taman bacaan masyarakat secara maksimal. Taman bacaan masyarakat merupakan area publik dan menjadi jantung pendidikan masyarakat. Oleh karena itu, diharapkan mampu memotivasi dan menumbuh kembangkan minat dan kegemaran membaca bagi masyarakat sehingga masyarakat menjadi warga belajar yang aktif. Taman bacaan dalam pengelolaan dan penyelengaraanya diperlukan pendampingan dari pihak penyelengara maupun instansi terkait. Hal ini dilakukan agar perjalanan taman bacaan masyarakat bisa mencapai tujuan sesuai yang diharapkan.

Minat dan kebutuhan masyarakat untuk gemar membaca memerlukan perhatian serius dari pemerintah dan masyarakat. Salah satu yang diperlukan dalam penyelengaran taman bacaan adalah perhatian khusus dari penyelengara dan instansi terkait dalam pelaksanaan pendampingan.

Wasti Sumanto berpendapat perhatian adalah pemusatan tenaga atau kekuatan jiwa tertentu kepada suatu obyek, atau pendayagunaan kesadaran untuk menyertai suatu aktivitas (Sumanto, 1990). Hal ini sesuai pernyataan Gol A. Gong dan Agus M. Irhkam dalam peningkatan minat baca terutama pada program taman bacaan masyarakat yang mempunyai kendala. Kendala tersebut dialami oleh program layanan masyarakat lainnya (Gong dan Irkham, 2011).

TBM Permata Hati merupakan tempat memperoleh pengetahuan dan sarana belajar nonformal bagi masyarakat khususnya para anak usia dini. Sebagai sumber belajar masyarakat, TBM Permata Hati mempunyai kegiatan yang dapat meningkatkan minat belajar masyarakat dengan memanfaatkan TBM Permata Hati.
Kegiatan membaca merupakan sumber belajar masyarakat, karena dengan membaca masyarakat belajar dan dapat menambah pengetahuan dan wawasannya. Taman bacaan masyarakat sebagai sumber belajar bagi masyarakat diharapkan dapat memberikan manfaat bagi para pengunjung dalam hal ini para anak usia dini. Untuk itu beberapa program taman bacaan Permata Hati yang telah dilakukan yakni a, Membaca ditempat, b, Meminjamkan buku, c, Pembelajaran. Dalam program pendampingan pembelajaran khusus untuk para anak-anak balita terutama pendampingan belajar membaca dan menulis dengan menggunakan berbagai pendekatan. Beberapa pendekatan dalam pendampingan belajar yakni (1) Membimbing teknik membaca (2) menulis kata dan kalimat( (3) Melaksanakan lomba-lomba, misalanya lomba kemampuan membaca, cerdas, cermat, dan lain-lain. Melalui program pelayanan yang disediakan oleh Taman Bacaan Permata Hati dapat memberikan manfaat kepada masyarakat sebagai berikut;

a. memberi pengalaman belajar secara langsung dan kongkret kepada para anak usia dini. Hal ini terlihat dengan adanya pelayanan pendampingan belajar membaca oleh para pengelola kepada para anak usia dini. Selain itu, disediakan pula koleksi-koleksi khusus anak seperti buku cerita bergambar yang sangat selaras dengan kebutuhan anak-anak.

b. dapat memperluas dan menambah cakrawala para pengunjung. Manfaat ini lebih dirasakan oleh para orang tua anak usia dini dengan disediakannya pelayanan koleksi umum seperti majalah, buku-buku teknologi tepat guna, buku-buku panduan dan lain-lain. 
Tersedianya koleksi tersebut membantu para orang tua yang mengantar anak belajar di TBM sekaligus memanfaatkan waktu luangnya untuk membaca dan berdiskusi mengenai berbagai hal. Termasuk didalamnya berdiskusi mengenai cara mengajar atau mendampingi anak untuk berlatih membaca

c. dapat membantu memecahkan masalah pendidikan kususnya bagi para ibu rumah tangga muda yang memiliki kesibukan sebagai ibu rumah tangga sekaligus sebagai pekerja. Tersedianya pelayanan membaca oleh Taman Bacan Permata Hati ini anak-anak usia dini masih tetap terdampingi untuk terus belajar.

d. dapat meningkatkan kegemaran membaca sejak dini. Dengan selalu diperkenalkan kepada berbagai koleksi buku, koran, dan majalah anak diharapkan dalam diri anak-anak usia dini ini terbentuk jiwa gemar membaca. Seperti kita ketahui bahwa pada masa usia dini merupakan usia emas bagi perkembangan anak baik secara fisik, psikologis, maupun intelegensi. Oleh karena itu, pada usia inilah masa-masa terbentuknya karakter anak sehingga penanaman nilai-nilai kehidupan seharusnya harus ditanamkan secara komprehensip pada masa ini.

Dari uraian tersebut dapat disimpulkan taman bacaan masyarakat ini sangat bermanfaat bagi masyarakat karena dapat memberi kesempatan kepada mereka memperoleh peningkatan pengetahuan dan keterampilan serta harapan dalam meningkatkan taraf kehidupan. Peningkatkan pengetahuan dan keterampilan jika dikelola dengan baik, akan menjadikan mereka sebagai sumberdaya manusia yang memiliki keunggulan kompetitif yang mampu bersaing di lapangan pekerjaan.

Disamping itu, keunggulan kompetitif tersebut membuka peluang bagi mereka untuk dapat memasuki dunia kewirausahaan terutama dalam mengelola produk unggulan daerah. Dengan bimbingan dan dukungan dari berbagai pihak diharapkan masyarakat pada daerah ini dapat berwirausaha sesuai dengan kemampuanya. Pada akhirnya, mereka melalui kemampuan usaha ini dapat memiliki pendapatan yang tetap sehingga tidak lagi menjadi pengangguran. Adanya kerjasama sinergis dengan semua pihak diharapkan taman bacaan masyarakat ini dapat berperan dalam mencerdaskan dan meningkatkan kesejahteraan masyarakat. Khususnya masyarakat kurang mampu sehingga mereka tidak lagi berada dalam posisi sebagai masyarakat pra sejahtera tetapi menjadi masyarakat sejahtera.

\section{SIMPULAN}

Berdasarkan data hasil pembahasan dapat disimpulkan bahwa taman bacaan masyarakat Permata Hati dapat berperan dalam meningkatkan belajar anak usia dini. Hal ini terlihat dari peran taman bacaan tersebut yakni sebagai sumber belajar masyarakat, sebagai sumber informasi, dan sebagai sumber hiburan. Secara rinci peran taman bacaan Permata Hati dapat disimpulkan sebagai berikut. Taman bacaan masyarakat sebagai sumber belajar masyarakat yang diharapkan dapat memberikan manfaat bagi para pengunjung dalam hal ini para anak usia dini. Beberapa program Taman Bacaan Permata Hati yang telah dilakukan yakni membaca ditempat, meminjamkan buku, pendampingan pembelajaran. Dalam program 
pendampingan pembelajaran khusus untuk para anak-anak balita, terutama pendampingan belajar membaca dan menulis dengan menggunakan berbagai pendekatan diantaranya membimbing teknik membaca, menulis kata dan kalimat, melaksanakan lomba-lomba, misalnya lomba kemampuan membaca, cerdas, cermat, dan lainlain.

Taman Bacaan Masyarakat Permata Hati berperan sebagai sumber informasi. Masyarakat dapat memperluas dan menambah cakrawala. Manfaat ini lebih dirasakan oleh para orang tua anak usia dini dengan disediakannya pelayanan koleksi umum seperti majalah, buku-buku teknologi tepat guna, buku-buku panduan dan lain-lain.

Taman bacaan masyarakat Permata Hati berperan sebagai sumber hiburan. Hal ini sebagai inplikasi tersedianya koleksi buku bacaan ringan seperti cerpel, novel, buku resep makanan, dan majalah. Selain itu, masyarakat datang ke taman bacaan untuk berkumpul, dan mengobrol sehingga dapat mempererat hubungan antar sesama pengunjung.

\section{DAFTAR PUSTAKA}

Eliasa, E. I. (2011). Pentingnya Kelekatan Orangtua dalam Internal Working Model untuk pembentukan Karakter Anak (Kajian Berdasarkan Teori Kelekatan dari John Bowlby). dalam Karakter Sebagai Saripati Tumbuh Kembang Anak Usia Dini, Yogyakarta: Inti Media Yogyakarta bekerjasama dengan Pusat Studi Pendidikan Anak Usia Dini Lembaga Penelitian Universitas Negeri Yogyakarta.
Direktorat Pendidikan Masyarakat, D. P. D. P. P. (2008). Konsep Taman Bacaan Masyarakat Pendidikan Nasional. Jakarta: Depdiknas.

Direktorat Pendidikan Masyarakat, D. P. D. P. P. (2009). Keaksaraan dalam Wacana Global: Media Komunikasi Pendidikan Keaksaraan (Aksara). Jakarta: Dinas Pendidikan dan Kebudayaan.

Direktur Jenderal Pendidikan Anak Usia Dini, Nonformal, dan I. (2012). Petunjuk Teknis Pengajuan dan Pengelolaan Taman Bacaan Masyarakat (TBM) Ruang Publik. Jakarta: Kementerian Pendidikan dan Kebudayaan.

Djohani, R. (2003). Partisipasi, Pemberdayaan, dan Demokratisasi Komunitas: Reposisi Participatory Rural Appraisal (PRA) dalam Program Pengembangan Masyarakat. Bandung: Studio Driya Media.

Gong, G. A. dan Irkham, A. I. (2011). Gempa Literasi: Dari Kampung untuk Nusantara. Jakarta: Gramedia Pustaka Utama.

Menteri Pendidikan Nasional R.I. UndangUndang Republik Indonesia Nomor 20 Tahun 2003 tentang Sistem Pendidikan Nasional (2003). Jakarta: Menteri Pendidikan Nasional R.I.

Menteri Pendidikan Nasional R.I. Menteri Pendidikan Nasional No. 48 Tahun 2010 mengenai penguatan dan perluasan (2010). Jakarta: Menteri Pendidikan Nasional R.I.

Saepudin, E. (2016a). Literasi Media Bagi Guru Paud Di Kecamatan Cicalengka. Dharmakarya, 5(1), 39.

Saepudin, E. (2016b). Tingkat Budaya Membaca Masyarakat (Studi Kasus Pada Masyarakat Di Kabupaten Bandung). Jurnal Kajian 
Informasi dan Perpustakaan, 3(2), 276. Sumanto, W. (1990). Psikologi Pendidikan. Retrieved from http://jurnal.unpad.ac.id/jkip. Jakarta: Rineka Cipta. 